\title{
LA LEY DE DEFENSA DE LA REPÚBLICA DE 21 DE OCTUBRE DE 1931: INTRODUCCIÓN A SU CONTEXTO POLÍTICO-JURÍDICO, A SU NORMATIVA CONEXA Y BREVE COMPARATIVA CON SU HOMÓNIMA ALEMANA, LA GESETZ ZUM SCHUTZE DER REPUBLIK*
}

\author{
Alberto Oehling de los Reyes \\ doi: 10.18543/ed-64(2)-2016pp127-155
}

\begin{abstract}
SUMARIO. I. INTRODUCCIÓN. II. LA PRE-NORMATIVA EN MATERIA DE DEFENSA INTERNA EXTRAORDINARIA DE LA REPÚBLICA. III. LA LEY DE DEFENSA DE LA REPÚBLICA DE 21 DE OCTUBRE DE 1931. IV. EL SUPUESTO MODELO: LA LEY DE PROTECCIÓN DE LA REPÚBLICA ALEMANA. V. LA POST-NORMATIVA EN MATERIA DE DEFENSA INTERNA EXTRAORDINARIA DE LA REPÚBLICA.
\end{abstract}

\section{INTRODUCCIÓN}

La II República española nació en un contexto político-jurídico no del todo propicio. En lo que se refiere a las circunstancias políticas del nuevo régimen, en primer lugar, porque alguno de los actos de impulso hacia el sistema republicano habían tenido un menor o mayor cariz violento, muy en particular, la Sublevación de Jaca de Fermín Galán y del Aeródromo de Cuatro Vientos de Ramón Franco y Queipo de Llano en 1930'; en segundo lugar,

* El estudio de la normativa y del material utilizado para la parte de este trabajo dedicada a la Gesetz zum Schutze der Republik, se realizó aprovechando una estancia de 
porque la nueva República no traía consigo en realidad todos los apoyos sociales que hubiera querido desear, como se entrevé ya en el resultado de los no del todo determinantes comicios municipales de 12 de abril de $1931^{2}$, a la postre referéndum Monarquía-República ${ }^{3}$. En realidad, con qué apoyo mayoritario objetivo nacía la nueva España no estaba, en el fondo, nada claro. Desde el principio, se vería que el nuevo régimen no sólo no gozaba del apoyo de los monárquicos, sino tampoco de otros sectores que se hubieran presupuesto más afines al cambio de sistema, como los partidos de la izquierda radical. Después, las numerosas declaraciones de estado de guerra

investigación en el Max-Planck-Institut für aüslandiches und internationales Strafrecht, en Friburgo, durante el mes de agosto de 2016.

1 Sobre las escaramuzas y bajas en la Sublevación de Jaca entre la columna de sublevados, policía, Guardia Civil y el Ejército gubernamental, véase, por ejemplo, TUÑóN DE LARA, M., «La Sublevación de Jaca», Historia 16, n. ${ }^{\circ} 1$ (1976): 63-64; AzPIROL PASCUAL, J. M. a y Elboj Broto, F., La sublevación de Jaca (Zaragoza: Guara, 1984): 27-36, 109117. Respecto al conato de Cuatro Vientos, organizado por Ramón Franco, Pablo Rada, Queipo de Llano e Hidalgo de Cisneros, entre otros, fuera de la toma del aeródromo militar por los sublevados, no conllevaría bajas, puesto que el plan de bombardear el Palacio de Oriente desde el aire por Ramón Franco se frustró por éste cuando, antes del bombardeo, vio niños jugando en los aledaños del palacio; lanzando, en su lugar, octavillas en favor de la República. Véase el testimonio del piloto en Franco, R., Madrid bajo las bombas (Madrid: Zeus, 1931): 164-174.

239.248 concejales republicanos electos frente a los 41.224, según MARTínEZ CuADRADO, M., en Elecciones y partidos políticos en España (1868-1931) (Madrid: Taurus, 1969), 855.; 22.150 monárquicos frente a la quinta parte republicanos (5.875) de un total de 28.025 concejales a elegir, según García-Gallo, A., Manual de Historia del Derecho, Vol. I (Madrid: Artes Gráficas y Ediciones, S.A., 1977), 962; en las capitales de provincia, los republicanos sacaban clara mayoría, obteniendo 953 concejales frente a los 602 monárquicos, según Aguirre, P., Begné, A., y Woldenberg, J., Sistemas políticos, partidos y elecciones: Estudios comparados (México D.F.: Nuevo Horizonte Editores, 1997), 113. En cambio, el Anuario Estadístico de 1931, INE 1932-1933 (Tabla IX), que da cifras de los concejales elegidos en las elecciones de 12 de abril de 1931 facilitadas por las respectivas Juntas municipales del Censo Electoral, ofrece los siguientes números: Concejales proclamados por el artículo 29 de la Ley Electoral de 1907 (de elección inmediata, sin necesidad de votaciones, por presentación de un único candidato o por presentación de igual número de candidaturas que puestos de concejales a cubrir), 13.940 republicanos, 887 socialistas, 6.065 monárquicos, 10 comunistas y 6.043 de otros partidos; Concejales elegidos por votación, 20.428 republicanos, 3.926 socialistas, 12.970 monárquicos, 57 comunistas y 9.155 de representantes de otros partidos. Véanse las tablas por provincias en la página Web del INE en <http://www.ine.es/inebaseweb/search.do?monoSearchStri $\mathrm{ng}=$ concejales $>$.

3 Véase así, por ejemplo, Oliver Araujo, J., El sistema político de la Constitución de 1931 (Palma: Universidad de las Islas Baleares, 1991), 23. 
en muchos lugares de España desde los inicios de la República4, así como, más tarde, la rebelión de Sanjurjo de 1932 y la propia Revolución de 1934, demostrarían, de algún modo, la dificultad continua que tuvo la República para romper esta situación de desafecto, confrontación y caos y poder llegar a asentar el régimen en un clima de normalidad política mínima. La aparición de bandas de paramilitares de izquierdas y derechas obviamente empeoraría mucho la situación, pues, de alguna manera, se puede decir que no cejaron durante todo el periodo de inicio y consolidación de la República de realizar actuaciones de desestabilización del régimen. Ya desde la primavera de 1933 Lister reconocía que los comunistas, a través del MAOC (Milicias Antifascistas Obreras y Campesinas) disponían de un manípulo instruido en formación militar, lo mismo que las Juventudes Socialistas, que también tenían sus fuerzas clandestinas de choque ${ }^{5}$. El 29 de octubre de 1933 José Antonio había creado la Falange, también con estructura e incluso atuendo militar ${ }^{6}$. Los anarquistas, la FAI y la CNT, también llevaban a cabo una especie de terrorismo callejero y de guerra de guerrillas que solamente entre abril de 1931 y diciembre de 1933 costó la vida a nada menos que 221 personas ${ }^{7}$.

${ }^{4}$ La prensa se haría eco de las sucesivas declaraciones de estado de guerra del momento por revueltas anticlericales, quemas de conventos o revoluciones a nivel provincial. Véase así, por ejemplo, la declaración de Estado de guerra en Sevilla el 16 de abril de 1931, en la noticia «El Gobierno provisional de la República continúa sus primeros trabajos de organización del nuevo régimen», en el diario $A B C$, edición del 17 de abril de 1931 , pp. 9 y 26; declaraciones de estado de guerra de Alicante, Cádiz, Málaga y Sevilla de 12 de mayo de 1931 y de Valencia de 13 de mayo, en la noticia «Breve resumen de información desde el día 11 de mayo hasta el 3 de junio», en el diario $A B C$, edición del 6 de junio de 1931, p. 37; «Levantamiento del estado de guerra en Córdoba», $A B C$, edición del 17 de junio de 1931, p. 22; «Ayer se declaró el estado de guerra en Gerona», $A B C$, edición del 18 de junio de 1931, p. 31; «Se levanta el estado de guerra en Gerona», $A B C$, edición del 19 de junio de 1931, p. 30; «Se levanta el estado de guerra en San Sebastián», $A B C$, edición del 21 de junio de 1931, p. 27; «Se levanta el estado de guerra en el Campo de Gibraltar», ibidem, p. 44; «Huelga general en Granada y Málaga, declaración del estado de guerra en esta última capital», en $A B C$, edición del 30 de junio de 1931, p. 47; «Del Estado de Guerra en Palma de Mallorca», en $A B C$, edición del 9 de julio de 1931, p. 51; «La gravedad de la situación en Sevilla obligó anoche a declarar allí el estado de guerra», en $A B C$, edición del 23 de julio de 1931, p. 19; «Ayer se levantó el estado de guerra en Sevilla», en $A B C$, edición del 30 de julio de 1931, p. 27.

5 Lister, E., Nuestra Guerra. Memorias de un luchador (Madrid: Silente, 2007), 60.

${ }^{6}$ Véase Primo De RiverA, P., Recuerdos de una vida (Madrid: Dyrsa, 1983): 59, 9396.

7 Payne, S. G. El colapso de la República: Los orígenes de la Guerra Civil (19331936) (Madrid: La Esfera, 2006): 80-81 y 566. 
En términos jurídicos la principal curiosidad sería la aprobación inmediata de la Ley de Defensa de la República de 21 de octubre de $1931^{8}$-que privaría de eficacia con cierto nivel de arbitrariedad un importante número de derechos ${ }^{9}$ - y su posterior constitucionalización a través de la disposición transitoria segunda en la Constitución de 9 de diciembre de 1931. Esto situaría al mismo texto constitucional en una posición excesivamente incoherente, en especial con el principio básico de supremacía constitucional, que derivaba de la paradójica supeditación de la norma constitucional a una ley preconstitucional ${ }^{10}$. El poder constituyente de la II República iniciaba su andadura así de una forma ciertamente confusa, puesto que así, como dice Fernández Segado, las garantías de los derechos constitucionales quedaban reducidas a la nada como consecuencia de la extensión de vigencia de dicha norma extraordinaria ${ }^{11}$. Lo cierto es que, dadas las circunstancias de excepcionalidad y tensión del momento, lo lógico hubiera sido no supeditar la Constitución a una norma ante-constitucional, aunque esta hubiera sido aprobada por el poder constituyente; sino al revés, sin zarandajas haber dispuesto en la propia Constitución un capítulo de suspensión extraordinaria de derechos y libertades, constitucionalizando las posibles facultades gubernativas de suspensión de derechos y, aparte, determinando las posibles vías de control parlamentario de dichas medidas. En cambio esto no sólo no se hizo, sino que, además, finalmente se utilizarían además muchos preceptos legales y tics policiales de la Monarquía, lo que, a la postre, alimentaría aún más, si cabe, la desconfianza social en el nuevo sistema, dando por resultado, por un lado, un incremento de las acciones de los paramilitares y radicales; por otro, la utilización constante del Ejército para problemas domésticos de seguridad pública.

\section{LA PRE-NORMATIVA EN MATERIA DE DEFENSA INTERNA EXTRAORDINARIA DE LA REPÚBLICA}

La II República se desarrolló constantemente en un clima creciente de inestabilidad político-social interna. En los primeros años, además, esta

${ }^{8}$ Para el análisis de la norma y de la Constitución de 9 de diciembre de 1931, hemos utilizado la selección de textos históricos españoles de Tierno Galván, E. (Comp.), Leyes politicas españolas fundamentales (1808-1978) (Madrid, Tecnos: Madrid, 1979), 172-191.

9 Fernández Segado, F., «La defensa extraordinaria de la República», Revista de Derecho político 12 (1981): 110.

${ }^{10}$ Sobre los apoyos y críticas a la Ley de Defensa de la República, véase FerNÁNDEZ SEgADO, «La defensa extraordinaria de la República», 110 y 111, 117-119; el mismo autor en Las Constituciones históricas españolas (Madrid: Civitas, 1986): 456-464.

11 Fernández Segado, Las Constituciones históricas..., 528. 
situación se agravaba por la situación económica derivada de la crisis de 1929, que produjo en nuestro país una fuerte caída del volumen del comercio exterior, salida de capitales y un parón en la inversión, con la consecuente subida del número de desempleados y la conflictividad social ${ }^{12}$. Por su parte, los excesos de orden público incluían quema de conventos e iglesias, asaltos a periódicos, revueltas y asesinatos por razones de tipo político. Según las estadísticas, en el periodo del Gobierno Provisional, el número de estados de guerra fue de 7, de un total de 20 hasta 1936; 64 muertes violentas por motivos de tipo político, ascendiendo a un total de 400 hasta $1933^{13}$ y de 2.225 hasta $1936^{14}$. El número de huelgas en 1931 fue de 734 de un total de 3.078 que se produjeron hasta el inicio de la Guerra Civil ${ }^{15}$. Por eso, cuando la República empieza a hacerse cargo del Estado y de la protección interna del nuevo régimen, desde el principio, lo hará a partir de la Ley de Orden Público de la Monarquía y cuando diseñe su propia norma de seguridad ciudadana, en 1933, lo hará además manteniendo vigentes muchos de los principios y previsiones de la norma anterior. En este contexto, el Ejército tomaba una posición destacada, pues, de acuerdo a la Ley de Orden Público de 23 de abril de 1870, cuando la autoridad civil no pudiera, por sí sola, a pesar del uso de potestades de policía excepcionales, restablecer el orden público, podía hacer uso de la fuerza

12 Véase así SAncho Flórez, J. G., La Segunda República española (Madrid: Akal, 1997), 53-54.

13 Avilés Farre, J., Elizalde Pérez-Grueso, M. D., Sueiro Seoane, S., Historia politica de España, 1875-1939, Vol. I (Madrid: Istmo, 2002), 347; PINO ABAD, M., «Los delitos contra el orden público en el marco de la Ley de defensa de la República de 21 de octubre de 1931», Anuario de Historia del Derecho español 82 (1982), 744.

${ }^{14}$ Linz, J. J., Montero J. R., y Ruiz, A. M. R., «Elecciones y política», en CARreras, A., y TAFunell, X., (Coord.), Estadísticas históricas de España (Siglos XIX y XX) (Bilbao: Fundación BBVA, 2005),1144-1146; PAYNE, S. G., El colapso de la República..., 566 y 567. En el último periodo antes del levantamiento, las cifras de asesinatos políticos subirían exponencialmente, como, por ejemplo, indica RuIZ, J., en El Terror rojo (Barcelona: Espasa, 2012), 38 y 39, quien da cifras, solamente de febrero hasta el 17 de julio de 1936, de hasta 444 asesinatos políticos.

${ }_{15}$ En 1931, 734 huelgas, con una participación estimada de 284.208 huelguistas; en 1932, 681 huelgas, con una participación estimada de 421.331 huelguistas; en 1933, 1.127, con una participación estimada de 908.364 huelguistas; en 1934, 594 huelgas, con una participación estimada de alrededor de 809.459; en 1935, 181, con una participación de 53.609; y en 1936, 887 huelgas, con una participación estimada de 809.495. LiNZ, J. J., Montero, J. R., Maluquer de Motes, J., Lonch, M., «Trabajo y relaciones laborales», en CARreras. A., y TAFunell, X., (Coord.), Estadísticas históricas de España..., 1242. Véase también una estadística con cifras ligeramente más bajas en TAMAMES, R., La República. La era de Franco (Madrid: Alianza, 1973), 119 y 121. Para más datos estadísticos, véase la página Web del INE, en <http://www.ine.es/inebaseweb/search. do?monoSearchString=empleados $>$. 
militar, también a través de la declaración del estado de guerra ${ }^{16}$. Independientemente del deseo personal de Azaña, de preferir mantener al Ejército sin intervenir y utilizar solamente a los cuerpos de seguridad del Estado en los casos de alteración del orden público -muy violentos, por otra parte, y difíciles de controlar, sobre todo en las revueltas anarquistas y en la Revolución de 1934-, lo cierto es que la única alternativa de profilaxis era la utilización de la fuerza militar; posibilidad, por otra parte, incluso reconocida en la Ley de Orden Público de 1870, vigente en los inicios de la II República ${ }^{17}$.

La Ley de Orden Público de 1870 era muy efectiva. Sus ventajas devenían de que era una norma muy represiva, típica del siglo XIX, muy renuente con el mantenimiento de las garantías individuales en casos de alteraciones del orden público. La propia Exposición de Motivos del Decreto de proyecto de reforma de la Ley de Orden Público de 1933 reconocía las bondades y la aplicabilidad de la Ley de 1870 a tales efectos ${ }^{18}$. En el fondo, las posibilidades de restricción de derechos individuales que determinaba la Ley de 1870, de acuerdo a las Constituciones vigentes de cobertura, requería la anterior aprobación por las Cortes de una ley previa de suspensión temporal de garantías constitucionales (artículo 31 de la Constitución de 1869); y solamente por razones de gravedad y urgencia podía realizarse por el Gobierno (artículo 17 de la Constitución de 1876) ${ }^{19}$. Esta previsión -que la propia Ley de Orden Público indicaba en su artículo 1-, no obstante, en los inicios de la II

16 Artículo 12 de la Ley de Orden Público de 23 de abril de 1870. Gaceta de Madrid, n. ${ }^{\circ} 264$, de 12 de septiembre, pp. 1799-1801.

17 Compárese Salas LarrazÁBal, S., Los datos exactos, de la Guerra Civil (Madrid, Drácena, 1980), 33.

18 Véase el texto del Ministro de Gobernación, Casares Quiroga, presentando a las Cortes el Proyecto de Ley de Orden Público, de 6 de abril de 1933, cuando dice que «la Ley de Orden Público de 23 de abril de 1870 era excelente para su tiempo y llena De aciertos (...); tan es así que muchas de sus prescripciones no han envejecido todavía». Gaceta de Madrid, n. ${ }^{\circ} 117$, de 27 de abril, p. 654.

19 De acuerdo al artículo 1 de la Ley de Orden Público de 1870, estas previsiones solamente podían aplicarse toda vez que se dictara por las Cortes, con carácter previo, una ley de suspensión de garantías constitucionales, y se dejarían de aplicar cuando las Cortes levantaran sus efectos, restableciéndose así la vigencia de los derechos individuales reconocidos constitucionalmente. La propia Constitución de 1869 así lo determinaba también en el artículo 31, cuando decía que las garantías de libertad personal, residencia, inviolabilidad domiciliaria, libertad de expresión, libertad de imprenta, reunión y asociación únicamente podían suspenderse temporalmente y por medio de una ley y solo por razones extraordinarias de seguridad del Estado. En términos similares se expresaba el artículo 17 de la Constitución de 1876, si bien apuntando que, en caso de que no se pudieran reunir las Cortes en orden a la decisión de tal suspensión temporal, podría quedar decretada la misma por decisión unilateral del Gobierno, sometiendo su decisión al Parlamento tan pronto como fuera posible. 
República, quedaba cubierta por la excepcionalidad del cambio de régimen y por el propio Estatuto del Gobierno Provisional de 14 de abril de 1931, que reconocía motu proprio la facultad del Ejecutivo de someter temporalmente los derechos a «fiscalización gobernativa». La restricción de las garantías habilitaba a la autoridad civil a la adopción de "cuantas medidas preventivas y de vigilancia fueran convenientes a fin de asegurar el orden público», y en particular: a la detención de cualquier persona que se considerase necesaria, forzar el cambio de residencia del sujeto o su destierro, la entrada en el domicilio de un sospechoso sin su consentimiento y al examen de sus efectos, pertenencias y papeles; así como la disolución de grupos auxiliares de la revuelta y la suspensión de publicaciones que secundaran la comisión de delitos contra la seguridad interior y el orden público. En el caso de que la autoridad civil «no pudiera por sí sola, ni auxiliada con la judicial, dominar la agitación», cabía entonces la adopción, en comandita con la autoridad judicial y militar del territorio ${ }^{20}$, del estado de guerra; pudiendo la fuerza militar, en estos casos, realizar las mismas funciones de policía que la civil para la represión de la rebelión, también en lo que se refiere a la detención y privación del derecho a la libertad personal ${ }^{21}$.

La «defensa extraordinaria del régimen» también se determinó a través de la modificación de la normativa penal ${ }^{22}$. Por un lado, el mismo 15 de abril de 1931, se procedió a la derogación inmediata del Código Penal de 1928 de Primo de Rivera, considerado por el Gobierno Provisional, posiblemente, excesivamente duro con la delincuencia común ${ }^{23}$. Y, por otro lado, se reinstauró -modificándolo-, por Decreto de 2 de mayo de $1931^{24}$, el Código de 1870, que estaría vigente hasta que la República aprobó el nuevo texto de 1932 y su Ley adicional de Vagos y Maleantes de 4 de agosto de 1933. Asimismo, por el mismo Decreto de 2 de mayo, se modificaban el Código de Justicia Militar de 1890 y el Código Penal de la Marina de Guerra de 1888. Las reformas iban dirigidas a cambiar las disposiciones protectoras de la monarquía, trocándolas por previsiones de defensa de la República, por ejemplo, sustituyendo en el Código Penal ordinario de 1870 la mención al «Reino» por

${ }^{20}$ Véase también el Decreto de 29 de octubre de 1931. Gaceta de Madrid, n. ${ }^{\circ}$ 304, de 31 de octubre, pp. 627 y 628.

${ }^{21}$ El artículo 31 de la Ley de Orden Público de 1870 establecía: «La autoridad militar en el estado de guerra podrá adoptar las mismas medidas que la civil y las demás a que esta ley autoriza. Cuidará muy especialmente de que los jefes o comandantes de las fuerzas que conduzcan presos -ya a disposición de su autoridad, ya de la civil o judicial-, la verifiquen con toda seguridad al punto de destino».

22 Fernández Segado, F., «La defensa extraordinaria de la República», 109.

${ }_{23}$ Véase García Rosauro, G., «La aplicación del Código Penal de 1928 en la región de Murcia», Mvrgetana 126 (Murcia: Real Academia Alfonso X el Sabio 2012): 79-90.

${ }^{24}$ Gaceta de Madrid, n. ${ }^{\circ} 123$, de 3 de mayo, pp. 494 y 495. 
«República española», donde ponía «Rey», citando «Jefe del Estado», y donde antes se tipificaban los delitos contra un «Ministro de la Corona» se apuntaba ahora la figura del «Ministro de la República». La modificación incluía los delitos contra la forma de Gobierno de la II República, fijando como punible cualquier acto encaminado -por la fuerza o fuera de las vías legales- al restablecimiento de la monarquía o aquellos actos encaminados a substraer al Gobierno Provisional de sus facultades ejecutivas y legislativas. Igualmente, perfilaba el delito de rebelión en sus dos vertientes: civil y militar. El Decreto definía, grosso modo, la rebelión como subversión pública y en abierta hostilidad contra el Gobierno de la República ${ }^{25}$, y la rebelión militar como la sublevación en armas dirigida o auxiliada por militares contra la República y sus órganos institucionales ${ }^{26}$. Ambas modalidades podían llegar a ser condenadas incluso con la pena capital, si bien, por ejemplo, en el caso de Sanjurjo, aun cuando fue sentenciado a muerte por un consejo de guerra ${ }^{27}$, Azaña

${ }^{25}$ El Decreto de 2 de mayo de 1931 reformaba el artículo 243 del Código Penal de 1870 en los siguientes términos: «Son reos del delito de rebelión los que se alzaren públicamente y en abierta hostilidad contra el Gobierno para cualquiera de los objetos siguientes: 1.- Destituir al Jefe del Estado o deponer al Gobierno provisional de la República, o privarles de su libertad personal u obligarles a ejecutar un acto contrario a su voluntad; 2.- Impedir la celebración de elecciones para la Asamblea Constituyente y la reunión legitima de la misma; 3.- Impedir la celebración de las elecciones para Diputado a Cortes o Senadores; si las hubiere, en toda la República, o la reunión legítima de las mismas; 4.Disolver las Cortes o impedir la deliberación de alguno de los Cuerpos colegisladores o arrancarles alguna resolución; 5.- Sustraer la Nación o parte de ella o algún Cuerpo de tropa de tierra o de mar, o cualquiera otra clase de fuerza armada, de la obediencia al supremo Gobierno; 6.- Usar o ejercer por sí o despojar a los Ministros de la República de sus facultades propias o impedirles o coartarles su libre ejercicio». Sobre ello, SANDOVAL, J. C., El delito de rebelión (Valencia: Tirant lo Blanch, 2013), 55-66.

${ }^{26}$ Los puntos 8 y 9 del Decreto de 2 de mayo de 1931 reformaban, respectivamente, los artículos 237 del Código de Justicia Militar y 128 del Código Penal de la Marina de Guerra, determinando el delito de rebelión militar como sigue: «Son reos del delito de rebelión militar los que se alcen en armas contra la Constitución del Estado republicano, contra el Presidente de la República, la Asamblea Constituyente, los Cuerpos Colegisladores o el Gobierno provisional y legítimo, siempre que lo verifiquen concurriendo alguna de las circunstancias siguientes: 1.-Que estén mandados por militares o que el movimiento se inicie, sostenga o auxilie por fuerzas del Ejército; 2.- Que formen partida militarmente organizada compuesta de diez o más individuos; 3.- Que formen partida en menor número de diez, si en distinto territorio de la Nación existen otras partidas o fuerzas que se proponen el mismo fin; 4.- Que hostilicen a las fuerzas del Ejército antes o después de haberse declarado el estado de guerra». Véase, BALDovín RuIz, E., «El Código de Justicia Militar durante la Guerra Civil: 1936-1939», Revista de Historia Militar 113, (2013): 12 y 13 .

${ }_{27}$ El consejo de guerra para la determinación de la pena se podía aplicar a militares, pero también a civiles. La prensa de la época hacía eco de algunas reseñables. En el año 
finalmente - de conformidad con el artículo 102 de la Constitución- conmutaría el castigo por reclusión perpetua ${ }^{28}$. Y téngase en cuenta que en ambos ámbitos también se tipificaba como punible la sedición, a saber, la sublevación por la fuerza para impedir la promulgación de leyes, los actos de odio o vejación de la autoridad, la desobediencia a los agentes de los cuerpos de seguridad del Estado, los insultos a las autoridades o las instituciones y los desórdenes públicos ${ }^{29}$.

Insisto: en el objeto de análisis no sólo se debe examinar -aunque sea aproximadamente- el acierto o desacierto de las reformas del Gobierno Provisional de la II República, sino también la oportunidad y forma jurídicoconstitucional a través de la cual se llevaron a cabo. En el impasse que separa el inicio del nuevo régimen y la realización de elecciones a Cortes Constituyentes del 28 de junio de 1931 se formalizó una labor normativa exprés muy abultada, sobre materias sensibles, en particular en la orden a la labor de reforma y deconstrucción del Ejército ${ }^{30}$, con la sola excusa de que así se iba adelantando trabajo, dado que luego, seguramente, los miembros de las Cortes Constituyentes iban a refrendar la labor legislativa pre-constitucional. En cambio, lo cierto es que la ruptura con el sistema político anterior era muy reciente, no había sido del todo pacífica ni de apoyo unánime, razones por la cuales el afianzamiento de la República requería de respetar los tiempos, bus-

1932, por ejemplo, el diario ABC reseñaba el consejo de guerra por publicación de artículos que excitaban a la rebelión e injurias por parte de unos militares (véase $A B C$ de 6 de marzo, p. 31), por insulto a un superior $(A B C$ de 19 de marzo, p. 31) y por injurias al Ministro de la Guerra $(A B C$ de 16 de marzo, p. 31; y, en lo que se refiere a consejos de guerra contra civiles, por incitar a revueltas $(A B C$ de 16 de marzo, p. 26), por disparar a la Virgen de la Estrella en una procesión de Semana Santa ( $A B C$ de 20 de mayo, p. 36), por publicaciones clandestinas incitando a revueltas $(A B C$ de 4 de junio, p. 20), contra unos ciudadanos y unos militares que trataron de tomar un cuartel ( $A B C$ de 7 de agosto, p. 34), contra un concejal de Dos Hermanas por frases insultantes a la fuerza armada $(A B C$ de 14 de noviembre, p. 33).

28 Decreto de 25 de agosto de 1932, Gaceta de Madrid n. ${ }^{\circ}$ 239, de 26 de agosto, p. 1.475. Sobre ello, Thomas, H., Salas Larrazábal, R., y Viñas, A., La Guerra Civil española, Vol. I (Madrid, Ediciones Urbión, 1980), 181 y 182.

29 Véanse, respectivamente, los artículos 250-276 del Código Penal común de 1870, en la Gaceta de Madrid, n. ${ }^{\circ}$ 243, de 31 de agosto de 1870, pp. 15 y 16; artículos 243-265 del Código de Justicia Militar, en la Gaceta de Madrid n ${ }^{\circ}{ }^{279}$, de 6 de octubre de 1890, p. 76; artículos 136-142 del Código Penal de la Marina de Guerra, Gaceta de Madrid n. ${ }^{\circ}$ 249, de 5 de septiembre de 1888 , p. 681.

30 Sobre ello, OeHLING DE LOS ReYES, A., «La defensa y el Ejército en la II República española y en la Constitución de 1931: Aproximación y análisis desde una perspectiva constitucional», en Martín Martín, S., y VÁzquez Alonso, V., (Dirs.), Constitución de 1931: Estudios jurídicos sobre el momento republicano español, Marcial Pons, Madrid, 2017 (en prensa). 
car consenso y proceder a tal gran reforma con posterioridad a la aprobación de la Constitución e incardinando los conceptos de protección del régimen en el propio texto constitucional. Ello hubiera concedido a la República también al principio la fuerza de convicción que posee la aprobación de una norma constitucional como elemento de garantía de todos los sectores sociales, y hubiera permitido realizar la transición también con la legitimidad que dan unas elecciones democráticas en libre debate público de opciones y programas políticos. Era un momento de pedagogía constitucional, de contemporizar. No era el momento de proceder a una nueva «cuarentena» de las garantías individuales, de volver sobre las disposiciones de orden público de la Monarquía, ni de cambiar la bandera nacional por una totalmente nueva - cosa que, dicho sea de paso, según Vicente Rojo, «constituyó un grave error» y contribuyó al desafecto del Ejército y de parte de la sociedad a la República $^{31}-$, ni de idear formas de jubilación anticipada del gremio militar, ni de sustituir los días de los patrones de los cuerpos por un «Día del Ejército» ${ }^{32}$, como tampoco de hacer nimios y peregrinos cambios en los uniformes y distintivos de las Fuerzas Armadas. Muchas de las reformas de Azaña y del Gobierno de transición, también en materia de seguridad, realmente, eran cuestiones que podían perfectamente haber esperado a la aprobación de la Constitución; y las prisas, unido a la falta de aptitud ${ }^{33}$ y la capacidad de gestión de este tema, acabarían siendo, un nido de incoherencias que alimentarían el desafecto político, o, como apunta Tamames, «un semillero de violencia militar» que, a la postre terminarían por ser una de las principales causas de desaparición de la II República ${ }^{34}$.

${ }^{31}$ Véase el artículo de Javier Nart «Así explicó Vicente Rojo por qué la bandera de la República constituyó un gran error», en el diario $A B C$, edición de 2 de febrero de 2014, pp. 68 y 69.

32 Véase Puell de la Villa, F., Gutiérrez Mellado. Un militar del Siglo XX (19121995) (Madrid: Biblioteca nueva, 1997), 74. Algunas fiestas y patrones del Ejército y la Armada tenían además un origen centenario y gozaban de un arraigo muy fuerte en el seno de los distintos cuerpos. Piénsese, por ejemplo, en la Purísima Concepción, proclamada patrona de la Infantería española desde el día 7 de diciembre de 1585; en Santiago apóstol, con origen en el año 1170, o en la Virgen del Carmen, patrona de la Marina desde, al menos, el año 1791. Sobre ello, Hernández PARdo, P. (Coord.), Historia de las Fuerzas Armadas, Vol. V (Zaragoza: Edit. Palafox, 1984), 261-270.

${ }_{33}$ Véase así Payne, S. G., en El colapso de la República..., 491, cuando dice que «Azaña actuó con ineptitud con los militares (...) tratándolos como enemigos del nuevo régimen, pese a que no fue el caso», Más adelante (p. 547), indica que Azaña llevó a cabo una política militar que «generó hostilidad entre unos oficiales que, en principio, no eran hostiles a la República».

${ }^{34}$ Tamames, R., Breve Historia de la Guerra Civil española (Barcelona: Ediciones B, 2011), 28 . 


\section{LA LEY DE DEFENSA DE LA REPÚBLICA DE 21 DE OCTUBRE DE 1931}

La aprobación y vigencia de la Ley de Defensa de la República de 1931 supuso solamente un cambio relativo de las medidas de orden público y seguridad interna propias de la época de la Monarquía y la Dictadura de Primo de Rivera, puesto que siguieron permaneciendo vigentes en la nueva ley -en ralentí, por así decir- muchas fórmulas policíacas y de control típicas anteriores a la República. La adhesión de los diputados a la norma fue mayoritaria, en buena medida por la constante excepcionalidad de orden público en la que se encontraba el nuevo régimen desde su nacimiento ${ }^{35}$. No obstante, hubo diputados, como Juan Antonio Balbontín, que se caracterizaron por su acérrima oposición a la aprobación de la norma ${ }^{36}$ y que advertían de su sentido contradictorio con los nuevos principios republicanos y democráticos que el sistema pretendía instaurar y de que llevaría a un empeoramiento de la situación lejos de remediarlo. En algún debate parlamentario se tachó la misma de «fascista» y de amenaza de los derechos de los trabajadores ${ }^{37}$. Algún otro representante del Congreso, como Barriobero, decía de la ley que presuponía poner la República bajo la tutela policial ${ }^{38}$. Ossorio y Gallardo, y algún otro, en cambio criticaban la ley por su falta de garantías en el procedimiento sancionador ${ }^{39}$. Y, en efecto, en cierto modo, como igualmente indica Fernández de Castro, la aprobación de la Ley de Defensa de la República llevaría incluso a la aparición de medidas bastante represivas, posiblemente en algunos aspectos, más duras que las que había en la época de la Dictadura de Primo de Rivera ${ }^{40}$.

En cierta manera, la Ley de Defensa de la República contenía disposiciones que podían entrar dentro de posible lógica, dadas las circunstancias, como, por ejemplo, grosso modo, la consideración como actos de agresión al régimen la incitación a la desobediencia de las leyes y disposiciones de la

${ }^{35}$ Gomez-Reino y Carnota, E., «La libertad de expresión en la II República», Revista de Derecho Político 12 (1982): 175.

36 Véase así Álvarez Rey, L., Los diputados por Andalucía de la Segunda República 1931-1939 (Sevilla: Junta de Andalucía, 2009), 362.

37 Véanse los comentarios en el Diario de Sesiones del Congreso de los Diputados en García Santos, J. F., Léxico y política de la Segunda República (Salamanca: Universidad, 1980), 141 y 247; Fernández Segado, F., «La función de las Fuerzas Armadas en el estado de sitio, en el marco de la Constitución de 1978», en Prieto, L. / Bruquetas, C. (Edit.), Libertades públicas y Fuerzas Armadas (Madrid: Ministerio de Educación y Ciencia, 1986): 217 y 218.

38 GómeZ-Reino y CARNOtA, E., «La libertad de expresión en la II República», 175.

39 Ibidem, 176.

40 Fernández de Castro, I., De las Cortes de Cádiz al posfranquismo (1808-1956), vol I (Barcelona: Ediciones 2001, 1981), 189. 
República (artículo 1.1), la incitación a la indisciplina en las administraciones públicas (artículo 1.2), la comisión de actos violentos contra personas y cosas (artículo 1.4), la tenencia ilícita de armas y explosivos (artículo 1.7), la cesación injustificada de industrias o empresas (artículo 1.8), las huelgas realizadas al margen de las prescripciones legales (artículo 1.9) y la alteración injustificada del precio de las cosas (artículo 1.10). En cambio, otras prescripciones en ningún sentido se pueden considerar dentro de lo que se entiende por un Estado democrático y plural, en particular la restricción que hacía del derecho a la libertad ideológica, la libertad de información y expresión (artículos $1.3,1.5$ y 1.6). Por ejemplo, la norma entendía como «acto de agresión a la República», en términos genéricos la mera apología al régimen monárquico, así como el uso de emblemas, insignias o distintivos alusivos al mismo o las personas que lo representaban, de ahí que hasta no se pudiera siquiera tararear la Marcha Real -que se sustituyó por el himno de Riego primero y luego por la Internacional ${ }^{41}-$, y así, también, que un músico callejero pudiera ser sancionado, en aplicación de esta norma, por simplemente tocar el himno anterior con su acordeón en la terraza de un bar, o, asimismo, se pudiera proceder a instruir un procedimiento contra unos jóvenes, y clausurar un club deportivo, en razón de que se hubiera entonado en dicho club la Marcha Real $^{42}$. Hasta se llegó, como han puesto de manifiesto Fernández Segado ${ }^{43}$, Gómez-Reino ${ }^{44}$, Langa Nuño ${ }^{45}$, Pino $\mathrm{Abad}^{46} \mathrm{y} \operatorname{otros}^{47}$, a la suspensión de periódicos y publicaciones por la simple crítica con las Cortes constituyentes

${ }^{41}$ Sobre ello, véase, también, OeHLING DE Los ReYES, A., «El himno nacional como símbolo jurídico-constitucional en España: Cuestiones conexas, regulación y efectividad práctica», en HÄBERLE, P., El himno nacional como elemento de identidad cultural del Estado constitucional (Madrid: Dykinson, 2012), 26 y 27.

${ }^{42}$ Véanse estos casos extraídos de la prensa de la época, en Pettenghi Lachambre, J. A., Detrás del silencio. El trágico destino de los Gobernadores Civiles en la II República (Cádiz: Ed. Artes, 2009), 58 y 108. Sobre ello, véase, también, OEHLING DE LOS REYES, A., «El himno nacional como símbolo jurídico-constitucional en España: Cuestiones conexas, regulación y efectividad práctica», 26 y 27.

${ }^{43}$ Fernández Segado, F., «La defensa extraordinaria de la República», 118. 178.

${ }^{44}$ Gomez-Reino y Carnota, E., «La libertad de expresión en la II República», 174-

${ }^{45}$ LANGa NuÑo, C., «Notas para una historia de ABC de Sevilla desde sus inicios hasta el final de la Guerra Civil (1929-1919)», en PARIAS SÁinz M., Arias CASTAÑon, E., José Ruiz, M., y Barroso Villar, M. E. (Coord.,) Comunicación, historia y sociedad: homenaje a Alfonso Braojos (Sevilla: Universidad de Sevilla, 2001): 479-494.

46 PINO ABAD, M., «Los delitos contra el orden público...», 749.

${ }^{47}$ Cruz, R., «La prensa madrileña durante la II República»; Madrid, F., «La prensa confederal en la Segunda República: El diario CNT, 1932-1934», ambos en CASTILlo, S., y Otero Carvajal, L. E. (Edit.), Prensa obrera en Madrid 1855-1936 (Madrid: Consejería de Cultura, 1987), respectivamente, pp. 359-360 y 389-393. 
o el Ejecutivo de turno. Algunos diputados, Unamuno y otros, incluso llegaron a solicitar en las Cortes que se volviera a rehabilitar la anterior Ley de Prensa liberal monárquica de 1883, que, decían, «dejaba más libertad que el nuevo régimen republicano» ${ }^{48}$.

Aparte, estaba la arbitrariedad de determinación de sanciones y la falta de interdicción de la actuación gubernativa. El Gobierno, por vía del Ministro de Gobernación, podía, sin cortapisa alguna, suspender reuniones y manifestaciones con el único requisito (subjetivo) de sospecha de alteración de la paz pública, así como clausurar e intervenir todo tipo de centros y asociaciones (artículo 3). En tanto en cuanto, en muchos casos, los «actos de agresión a la República» quedaban fijados de una forma tan amplia e indeterminada -bajo conceptos de lesión de la paz pública, orden público, menosprecio a las instituciones, etc.-, lo cierto es que el Ministro de turno tenía bastante margen para determinar incluso, según criterio, cuando sí y cuando no se había producido una infracción. Luego, además, no había vía de protección jurisdiccional frente a la sanción, sino solamente vía administrativa ante el mismo Ministro en el brevísimo plazo de veinticuatro horas; en cambio, si se era persona colectiva, era el Consejo de Ministros quien resolvía la reclamación y había de interponerse en plazo de cinco días. Así pues, el Ejecutivo se situaba en la aplicación de la ley en un lugar muy peculiar y discrecional, como «juez y parte», dice Fernández Segado ${ }^{49}$, pues determinaba cuándo y porqué se había infringido la Ley de Defensa de la República, a qué medidas sancionadoras había lugar y, encima, era la entidad encargada de resolver las posibles reclamaciones del ciudadano por la sanción. Y téngase en cuenta que las sanciones de la Ley de Defensa de la República -que podían ser económicas, de separación del servicio, confinamiento y deportación (artículo 2)-, eran aparte acumulativas a las que, por los mismos motivos, pudieran determinarse por las provisiones de Derecho penal (artículo 6).

Además, la aparición de la Ley de Defensa de la República tampoco supuso una menor participación del Ejército en situaciones de alteración del orden público. Por ejemplo, en los disturbios de Burgos de 9 de noviembre de 1931, la sublevación anarquista del Alto Llobregat en Barcelona de 22 de enero de 1932 -por la que, precisamente, en aplicación de la Ley de Defensa de la República, en torno a doscientos implicados fueron deportados a África ${ }^{50}-$, y, más tarde, en los sucesos de Casas Viejas del 10 al 12 de enero de 1933, en donde hubo hasta 25 muertes, intervinieron la Guardia Civil y uni-

48 PINO ABAD, M., «Los delitos contra el orden público...», 754.

49 Fernández Segado, F., «La defensa extraordinaria de la República», 117.

${ }^{50}$ Sobre ello, con datos y explicaciones de la arbitrariedad de la medida, deportados de otras regiones de España y duras circunstancias de la travesía, véase PINO ABAD, M., «Los delitos contra el orden público...»: 753-754; PÉrez GARCÍA, G., «La colonia peni- 
dades de Infantería del Ejército ${ }^{51}$. La Guardia Civil era igualmente bastante utilizada como manipulo muy efectivo en la disolución por la fuerza de manifestaciones y represión de huelgas, como prueba su intervención, por ejemplo, en los sucesos del 3 y 4 de enero de 1932, con un saldo de cinco obreros heridos, los altercados de Arnedo, donde murieron once obreros y otros muchos resultaron heridos, y en los disturbios de Calatrava la Real en Ciudad Real, donde murieron otros dos trabajadores ${ }^{52}$. A veces, también se utilizaba al Cuerpo de Carabineros que, aunque estaba integrado en el Ministerio de Hacienda, se entendía como una «corporación militar»" ${ }^{53}$. De hecho, la República premió, en algún caso, por ley, la prestancia en la defensa del orden y de las leyes del régimen, con dinero y, en el caso de mandos y tropa, con ascensos ${ }^{54}$. Y téngase en cuenta que las veces en que solamente se utilizó a la policía de la República -los Guardias de Asalto- para tales menesteres tampoco deja de ser controvertido, ya que este cuerpo policial, muy temido ${ }^{55}$, con miembros de al menos 1,70 de altura ${ }^{56}$ (luego 1,72$)^{57}$, era también un reflejo del Ejército, con sus mismos empleos y divisas (de alférez a coronel en oficiales y de guardia, cabo a subteniente y brigada en suboficiales y escala de agentes), mismos escalafones, iguales técnicas y mandos provenientes de las Fuerzas Armadas ${ }^{58}$. La línea divisoria entre lo militar y lo policial, no estaba aún -como ocurría en la Monarquía-, por tanto, tampoco muy definida. La policía tomaba además nombres típicos de combate («Asalto», «de Vanguardia»), se organizaba en grados de jerarquía militar, compartía mandos con el Ejército y participaban ambos, mano a mano, según las circunstancias, en operaciones de mantenimiento del orden público.

tenciaria de Villa Cisneros. Deportaciones y fugas durante la Segunda República», en Historia y Comunicación social 7 (Madrid: UCM, 2002): 169-186.

51 Ballbé, M., Orden público y militarismo..., 340-342.

52 Pino ABAD, M., «Los delitos contra el orden público...», 751.

${ }^{53}$ Decreto de 19 de noviembre de 1932 (Preámbulo). Gaceta de Madrid n. ${ }^{\circ}$ 325, de 20 de noviembre, p. 1.246.

54 Gaceta de Madrid n. ${ }^{\circ}$ 229, de 16 de agosto de 1932, p. 1219.

55 Así Maura, M., Así cayó Alfonso XIII. De una dictadura a otra (Barcelona: Ariel, 1995), 274-276.

${ }_{56}$ Véanse las condiciones de acceso de la oferta de empleo público para la entrada en el Cuerpo de la Circular de 15 de marzo de 1932, Gaceta de Madrid n. ${ }^{\circ}$ 77, de 17 de marzo, pp. 1.950 y 1.951 .

57 Véanse las condiciones de acceso de la oferta de empleo público para la entrada en el Cuerpo de la Orden de 16 de septiembre de 1932, Gaceta de Madrid n. ${ }^{\circ}$ 261, de 17 de septiembre, pp. 2.013 y 2.014.

${ }^{58}$ Véase BALLBÉ, M., Orden público y militarismo..., 346. 


\section{EL SUPUESTO MODELO: LA LEY DE PROTECCIÓN DE LA REPÚBLICA ALEMANA}

En cierto modo, la II República española, en términos genéricos, tiene puntos contextuales de conexión con la República de Weimar en Alemania, y muchos de sus problemas de base que dificultaron su éxito eran equivalentes, aunque con sus peculiaridades y originalidades. La República de Weimar tampoco deviene de forma democrática, sino a través del levantamiento de los marineros de Kiel y la revolución de noviembre de 1918. Como en España, la República de Weimar se desenvolvió en un periodo económico muy delicado, tuvo también episodios revolucionarios de ultraizquierda muy desestabilizadores, golpes de Estado por parte de la ultraderecha; igualmente, sobrellevó un crecimiento constante de bandas paramilitares de ambos palos, muy numerosas y muy violentas, como la Bayerische Rote Armee, el Frente Rojo (Rotfrontkämpferbund) -la milicia armada del Partido Comunista alemán- y, por supuesto, los Freikorps y, después, la misma guardia del Partido Nacionalsocialista (Sturmabteilung) ${ }^{59}$. Ahora bien, hay distintos hechos que marcan unas diferencias importantes. En primer lugar, la coyuntura de postguerra y la difícil situación económica de Alemania en los inicios de la República de Weimar, que devenía de una política revanchista irrazonable de los vencedores de la Primera Guerra Mundial y presupuso unas obligaciones por reparaciones de guerra muy fuera de lo soportable para Alemania y que sobrepasaban en gran medida las capacidades económicas alemanas del momento $^{60}$. A ello se unía la toma simultánea por la fuerza, por parte del Ejército francés, de diversas ciudades de Alemania, primero en la zona de Maingau, en abril de $1920^{61}$, después -entre 1923 y 1925 - de la zona del Ruhr, a fin de forzar a Alemania al pago de las reparaciones de guerra, y que dejó un resultado de 137 muertos y 603 heridos $^{62}$. En segundo lugar, los sucesos golpistas y revolucionarios tuvieron distinta intensidad y gravedad. Por ejemplo, el golpe de Sanjurjo de 10 de agosto de 1932, solamente tuvo alrededor de 9 muertos $^{63}$, en cambio, su espejo alemán, que sería la intentona de Kapp y del General von Lüttwitz, de 12 de marzo de 1920, serían 42 los muertos y

${ }^{59}$ Para una comparativa de los hechos que llevaron a la desaparición de ambos sistemas, véase, GómEz CABORNERO, S., «Dos procesos paralelos hacia el final trágico de la democracia las culturas políticas de Weimar y de la II República española», en Investigaciones históricas: Época moderna y contemporánea 21 (2001):281-300.

${ }^{60}$ Así Zippelius, Kleine deutsche Verfassungsgeschichte (C.H. Beck, 2006), 136.

${ }^{61}$ Ibidem 137.

${ }^{62}$ Sturm, R., Weimarer Republik (Bonn: Bundeszentrale für politische Bildung, 2011) 31 .

${ }^{63}$ Ruiz Manjón-Cabeza, O., Historia general de España y América, Vol. 17 (Madrid: Editorial Rialp, 1986), 23. 
102 los heridos ${ }^{64}$; luego, además, habría que contar el Putsch de Hitler en München de 1923. En relación con los episodios revolucionarios de ultraizquierda, cabe señalar que, con excepción de la Revolución de Asturias de 1934, los levantamientos organizados y renuentes fueron algo más numerosos y respondidos con mucha más virulencia por la policía y los Freikorps, como, por ejemplo: el levantamiento espartaquista de 1919, con un resultado final de alrededor de 156 muertos, entre ellos incluso personalidades como Rosa Luxemburg y Karl Liebknecht ${ }^{65}$; la instauración por la fuerza de la República Soviética de Baviera, en abril de 1919, con una cifra de muertos que habría podido llegar a las 1000 víctimas ${ }^{66}$; la matanza ante el Reichstag del 13 de enero de 1920, con un resultado final de 42 muertos y 105 heridos $^{67}$, y la intentona comunista (la Roten Armee) de instaurar una República del proletariado en la zona del Ruhr, el 13 de marzo de 1920 y que dejó un saldo de alrededor de 1250 muertos $^{68}$. Aparte, se podrían citar otros levantamientos comunistas que fueron también importantes pero más rápidamente controlados como, por ejemplo, los de Eisenach, Gotha, Erfurt, Sonderhausen, Jena, Saalfeld, Hildburghausen y Walterhausen ${ }^{69}$, y, más tarde, en 1923, el alzamiento comunista en Hamburgo ${ }^{70}$. Y, finalmente, en tercer lugar, hay que decir que en España no hizo falta para llevar a cabo el proceso constituyente la configuración de una división militar específica-como pasó en Alemaniapara proteger a la Asamblea Constituyente durante sus trabajos parlamentarios, en especial frente a posibles ataques y revueltas de los comunistas. Aquel cuerpo de ejército, Landesjägerkorps, al mando del General Maercker, fue, además, trasladado ex profeso a la ciudad de Weimar para tal fin, fue colocado estratégicamente en las calles aledañas al Deutschen Nationaltheater, donde

${ }^{64}$ Así Benz, W. / Graml, H., Die revolutionäre Illusion (Berlín: De Gruyter, 1976), 175.

${ }^{65}$ Véase así HolsTe, H., «Zum Tagungsort der Deutschen Nationalversammlung von 1919 oder: Wie die Weimarer Republik zu ihrem Namen kam», en Zeitschrift für Parlamentsfragen 31-2 (2000), 227. Véase, también, WeTtE, W., Gustav Noske. Eine politische Biographie (Düsseldorf: Droste Verlag, 1987), 308.

${ }^{66}$ Véase Görl, W., «Die Revolution hat gesiegt», en KÄPPNER, J., Görl, W., MAYER, C. (Coord.), München. Die Geschichte der Stadt (München: Süddeutsche Zeitung, 2008), 271; MAI, G., Die Weimarer Republik (München: C. H. Beck, 2009), 28.

${ }^{67}$ ReIdegeld, E., Staatliche Sozialpolitik in Deutschland, Vol II (1919-1945) (Wiesbaden: VS Verlag für Sozialwissenschaften, 2006), 105.

${ }_{68}$ StURm, R., Weimarer Republik..., 26.

${ }^{69}$ LingelbaCH, G., «Weimar 1919 -Weg in eine Demokratie», en Eichenhofer, E. (Dir.), 80 Jahre Weimarer Reichsverfassung-Was ist geblieben? (Tübingen, Mohr Siebeck, 1999), 42.

${ }^{70}$ Huey Liang, H., Die berliner Polizei in der Weimarer Republik (De Gruyter, 1977), 112. 
se reunía la Asamblea, y fue dotado incluso de material especial ${ }^{71}$ e incluso tenía su propio distintivo, unas hojas de roble en plata ${ }^{72}$.

Se ha dicho que la Ley de Defensa de la República de 21 de octubre de 1931 venía influenciada por su homónima alemana, la Ley de Protección de la República (Gesetz zum Schutze der Republik) ${ }^{73}$. Quizás esto pueda ser así en algunos aspectos, pero no en todos. En España la República da paso a la Guerra Civil, en Alemania, en cambio, «el terror y la guerra civil acompañan la fundación de la República de Weimar» ${ }^{74}$. Para empezar, como se ha podido ver anteriormente, las circunstancias excepcionales que llevaron a la aprobación de la norma por el Canciller (Reichspräsident) Ebert y el Ministro de Justicia, Gustav Radbruch, fueron hechos mucho más violentas y difíciles de controlar que los que hasta ese momento habían sucedido en la República española; había sufrido ya la aparición de la República Soviética Independiente de Baviera, de abril de 1919, el golpe de Estado de Kapp y von Lüttwitz, de 12 de marzo de 1920, las actuaciones de los paramilitares (Freikorps), el asesinato por ultraderechistas del ex-Vicecanciller durante el Gabinete de Bauer Mattias Erzberger, el 26 de agosto de 1921, y, finalmente, el asesinato, también por ultras, del Ministro de Exteriores, Walter Rathenau, el 22 de junio de 1922, que fue, a la postre, lo que determinó la necesidad de aprobación de la ley ${ }^{75}$. También el ex-Presidente del Gobierno Scheidemann, quien declarara el día 9 de noviembre de 1919, desde el Reichstag la deutsche demokratische Republik -pocas horas antes, dicho sea de paso, de que Liebknecht

${ }^{71}$ El punto 1 de la orden de creación de este cuerpo decía que «los Landesjägerkorps deben proteger a la Asamblea Nacional y colaborar con la policía en el mantenimiento del orden y la paz». El punto 2 determinaba algunos de los lugares de la ciudad de Weimar donde debía posicionarse, concretamente en «el Hotel Hohenzollern, la Escuela profesional y el Seminario, cada una con una compañía, y en la estafeta de correos, además, con tren de artillería». Aparte la orden se completaba con el número de oficiales y hombres que debían integrar cada compañía, así como cuestiones especiales relativas al armamento; por ejemplo, «con ametralladoras MG-08 situadas en la casa esquina de la calle Sophienstiftsplatz para asegurar la Plaza del Teatro». Véase así LingeLBACH, G., «Weimar 1919 - Weg in eine Demokratie»..., 44-45.

${ }^{72}$ MAERCKer, L. R. G., Vom Kaiserheer zur reichswehr: geschichte des freiwilligen Landesjägerkorps; ein beitrag zur geschichte der deutschen revolution (Leipzig: Koehler, 1921), 92.

73 Véase así Manuel Ballbé, Orden público y militarismo en la España constitucional (1812-1983) (Madrid: Alianza, 1983), 327.

${ }^{74}$ Sabrow, M., Der Rathenaumord. Rekonstruktion eines Verschwörung gegen die Republik von Weimar (München: Oldenburg Verlag, 1994), 25.

75 Heiko Bollmeyer, Der Steinige Weg zur Demokratie. Die Weimarer Nationalversammlung zwischen Kaiserreich und Republik (Frankfurt am Main: Campus Verlag, 2007), 385-386; Uwe BACKeS, Schutz des Staates (Wiesbaden: Springer, 1998), 34 y 35. 
declaraba la freie sozialistische Republik desde el Palacio Real de Berlin ${ }^{76}$, y diputado de la Asamblea Constituyente, había sido objeto de pintadas con amenazas de muerte en su casa, e, incluso, el 4 de junio de 1922, de un intento de envenenamiento por ultraderechistas durante un paseo por el campo ${ }^{77}$. Así las cosas, no extraña que Radbruch, en su discurso en el Reichstag, el día 11 de julio de 1922, dijera expresamente que la primera razón de aprobación de la Ley de Protección de la República, de 21 de julio de $1922^{78}$, fuera, precisamente, prevenir frente a ataques a la misma vida de los miembros del Gobierno, aparte de proteger frente a insultos, amenazas, calumnias y difamación respecto a los altos cargos políticos y asegurar el régimen y sistema constitucional republicano recién instaurado ${ }^{79}$.

Luego, además, la Ley alemana era posterior a la Constitución de Weimar de 1919 y, de hecho, su elaboración se sujetó, al menos, a las prescripciones formales constitucionales y no al revés, como la norma española. Efectivamente, el artículo 48 de la Constitución de Weimar determinaba los casos de suspensión de la vigencia de la Constitución, pero como apuntaría Schmitt, de una «suspensión constitucional de la constitución», en el bien entendido de que «las prescripciones constitucionales serían provisionalmente puestas fuera de vigor con la observancia de las prescripciones legal-constitucionales previstas para tal suspensión ${ }^{80}$. Estructuralmente el artículo 48 estaba estructurado en cinco bases y venían en dotar, hasta cierto punto, de "poderes dictatoriales» al Ejecutivo para casos extraordinarios ${ }^{81}$. El artículo 48 inciso primero, determinaba la posibilidad del Reichspräsident, para casos en

76 WiLloweIt, D., Reich und Staat. Eine kleine deutsche Verfassungsgeschichte (München: C. H. Beck, 2013), 98; Neumann, K., Freiheit am Arbeitsplatz - Betriebsdemokratie und Betriebsräte in Deutschland und Schweden (1880-1950) (Frankfurt-New York: Campus, 2014), 170.

77 «Según su hija, que le acompañaba, fueron alcanzados por un excursionista que llevaba ropa deportiva y que llevaba en la mano izquierda un bastón de montaña y en la mano derecha un bolso que trataba de esconder. Tan pronto como llegó a la víctima, que no sabía qué le podía pasar, el sujeto sacó con su mano derecha una bola de goma del bolso y, dirigiéndose a este, mientras pasaba al lado derecho de Schiedemann, se puso justo delante y se la espachurró en la cara. Schiedemann se cayó y, posteriormente, se le encontraron restos de ácido cianhídrico, tanto en la mandíbula como en la nariz. Aun así, con el agarrotamiento de la parte superior del cuerpo y con las piernas tiradas en el suelo, pudo sacar su revólver y hacer unos disparos sin apuntar, antes de desvanecerse sin sentido». SABRow, M., Der Rathenaumord..., 57 y 58.

${ }_{78}$ El texto está disponible en alemán en $<$ http://www.documentarchiv.de/wr/ repschutz_ges01.html>.

79 RaDBruch, G., Reichstagsreden, Vol. 19 (Heidelberg: C. F. Müller, 1998), 113.

${ }^{80}$ Schmitt, C., Teoría de la Constitución (Madrid: Alianza Editorial, 1982), 116 y 117. Traducción de Francisco Ayala.

${ }^{81}$ Véase así Willowert, D., Reich und Staat..., 100. 
los que un Land no cumpliera las obligaciones constitucionales o legales, de forzarle a su cumplimiento, incluso con utilización de las Fuerzas Armadas. El inciso segundo -y este quizás es el más interesante a los efectos que aquí se tratan- determinaba que, para casos de peligro o alteración grave de la seguridad y el orden público, el Reichspräsident podía adoptar las medidas necesarias para el restablecimiento de la paz y tranquilidad pública, igualmente incluso con la intervención de las Fuerzas Armadas. Para estos casos, se podían llegar a suspender transitoriamente, totalmente o no, los derechos fundamentales indicados en los artículos 114, 115, 117, 118, 123, 124 y 153, a saber, grosso modo, los derechos a la libertad personal, a la inviolabilidad del domicilio, a la inviolabilidad en las comunicaciones, las libertades de expresión, comunicación, información y prensa, los derechos de reunión y manifestación, el derecho de asociación y el derecho a la propiedad privada. El inciso tercero incluía el control parlamentario de tales medidas, previendo que el Reichspräsident diera puntual noticia al Reichstag, el cual quedaba habilitado para revocarlas, si es que -se entiende- tenía una mayoría suficiente a tales efectos ${ }^{82}$. El inciso cuarto era una extensión de los poderes de suspensión del inciso segundo en favor del Ejecutivo del Land (Landesregierung), por razones de urgencia, si bien bajo previsión de revocación de las medidas adoptadas por parte del poder central, del Reichspräsident o por el Reichstag. El quinto inciso, en fin, determinaba un desarrollo por ley formal de esta cuestión.

Antes de la aprobación de la Ley de Protección de la República, tras el asesinato de Rathenau, el Reichspräsident Ebert, como primera medida de caución ante este estado de caos, bajo la cobertura del artículo 48 de la Constitución ${ }^{83}$, dicta el Decreto de Protección de la República (Verordnung zum Schutze der Republik), de 26 de junio de $1922^{84}$. El artículo 1.1 de aquella disposición determinaba medidas frente a las reuniones, manifestaciones y actuaciones que pudieran promover o incitar actuaciones contra la forma republicana o actos violentos contra las autoridades del Estado, los miembros del Gobierno o antiguos cargos del Ejecutivo o de las instituciones de los Länder; por otra parte (artículo 1.2), preveía la prohibición de asociaciones que realizaran dichos ilícitos. La norma incluía en su artículo 5.1 los tipos de ilícitos y las posibles sanciones que podían sobrellevar; en concreto, pena de cárcel de 3 meses a 5 años y, accesoria, de multa que podía llegar hasta los 500.000 marcos. La protección jurídica se articulaba en por vía de recurso en plazo de dos semanas desde la publicación del acto, si bien sin efecto suspensivo, ante la autoridad administrativa competente del Land

\footnotetext{
${ }^{82}$ Véase así MAI, G., Die Weimarer Republik, 29.

83 SABrow, M., Der Rathenaumord..., 161.

${ }^{84}$ Norma disponible en alemán en $<$ http://www.documentarchiv.de/wr.html $>$.
} 
(artículo 1.3), pero a resolver por el denominado Tribunal del Estado para la protección de la República (Staatsgerichtshof zum Schutze der Republik). Este Tribunal sería una magistratura ad hoc, creado dentro del poder jurisdiccional y con sede en Leipzig ${ }^{85}$, pero cuyos siete integrantes estarían designados por el mismo Reichspräsident, de los cuales solamente tres tenían que ser elegidos entre miembros de la judicatura (Reichsgerichts) ${ }^{86}$. Aparte, además, se preveía la suspensión judicial de publicaciones para casos de promoción e incitación de los actos determinados en el artículo 1. Posteriormente a esta disposición se añadiría el Decreto de 29 de junio de $1922^{87}$, que establecía incluso la pena de muerte o la cadena perpetua para aquellos que participaran en asociaciones o grupos de los que tuvieran conocimiento de que tenían entre sus fines atentar contra miembros del Ejecutivo del Reich o de un Land o ex cargos del Gobierno, o que participaran económicamente con dichas asociaciones. Estas disposiciones de tipo preventivo venían a completar, de algún modo, el cuadro de conductas tipificadas como delito en el Código Penal ${ }^{88}$, y se comprendían como un pre-borrador de la propia Ley de Defensa de la República posterior y dentro de las medidas del Canciller Ebert y el Gabinete del Presidente de la República Wirth para contener el caos, la violencia y la revolución ${ }^{89}$.

La primera Ley de Protección de la República, era de 22 de julio de $1922^{90}$, efectivamente, realizaba importantes restricciones de los derechos de asociación, reunión, manifestación y libertad de prensa, determinando, en concreto, como ilegales aquellas asociaciones que realizaran actuaciones dirigidas a la eliminación por asesinato o atentaran contra la integridad física de los miembros del Gobierno de la República o de un Land y sancionaba los insultos o difamaciones en público contra las instituciones, el régimen o los colores del Reich; pero, la norma, a la vez, precisaba bastante bien los distintos tipos de ilícitos y las posibles penas por la realización de los mismos, así como

${ }^{85}$ Véase Schulz, G., Deutschland am Vorabend der Grossen Krisse. Zwischen Demokratie und Diktatur (Berlin: De Gruyter, 1987), 325 y 326; WINKLER, H. A., Weimar 1918-1933. Die Geschichte der ersten deutschen Demokratie (München: C. H. Beck, 1993), 175.

${ }^{86}$ Este tribunal especial sería implementado también por Decreto sobre el Staatsgerichtshof zum Schutze der Republik, de 30 de junio de 1922 (Reichsgesetzblatt 1922 I, 534536), y, después, por el Decreto sobre la misma materia de 29 de julio de 1922 (Reichsgesetzblatt 1922, I, 673-674).

${ }^{87}$ Norma disponible en alemán en <http://www.documentarchiv.de/wr.html >.

${ }_{88}$ Véase así Goltsche, F., Der Entwurf eines Allgemeinen Deutschen Strafgesetzbuches von 1922 (Entwurf Radbruch) (Berlin-New York: De Gruyter, 2010), 55.

89 WinKLeR, H. A., Weimar 1918-1933 ..., 175.

${ }^{90}$ Reichsgesetzblatt 1922 I, 585-590. El texto está disponible en lengua alemana en $<$ http://www.documentarchiv.de/wr/repschutz_ges01.html $>$. 
las medidas dables de orden público y las vías de fiscalización o control judicial a llevar a cabo por el ya citado Tribunal del Estado para la protección de la República ${ }^{91}$.

En efecto, los artículos 7 y siguientes de la norma determinaban bastante claramente los ilícitos, a saber, en términos generales, el atentado contra los miembros del Gobierno del Reich o de un Land, participar de algún modo en su realización, proferir amenazas, calumnias, injurias contra ellos, la connivencia con un país extranjero para alterar la forma republicana del Estado, atentar contra los altos cargos del Estado y la tenencia, fabricación o tráfico de armas y explosivos para tales fines. Luego, en materia de sanción, repetía las penas de los decretos anteriores: de tipo general, de tres meses a cinco años, más la accesoria -esto sí cambiaba- de hasta un millón de marcos (artículos 7 y 8), y, como tipo especial, de pena de muerte o cadena perpetua para casos de intento o asesinato de miembros del Gobierno del Reich o del Land, $\mathrm{y}$, a su lado, de pena de cárcel no inferior a los cinco años para casos de simple participación (artículo 1); aparte se recogía ahora también la posible pena de destierro por periodos de hasta cinco años, la expulsión del territorio de Alemania, para casos de extranjeros, la pérdida de derechos políticos y de condición funcionarial y sueldo para casos de empleados del Estado (artículos 9 y 10). En materia de garantías, el Staatsgerichtshof zum Schutze der Republik, como señala Hueck, era un ente jurisdiccional del Reich, con competencias diversas, en el área del Derecho Penal, el Derecho Administrativo y en el Derecho Procesal Constitucional: era tribunal penal, por sus competencias de enjuiciamiento de delitos penales políticos contra la República o por alteración del orden público (en particular, atentado o tentativa contra la vida de los representantes del Estado); era tribunal administrativo, por su competencia para conocer sobre la realización de los ilícitos determinados en la norma por parte de asociaciones, partidos y agrupaciones de todo tipo y dirimir sobre la posible suspensión de publicaciones; $y$, finalmente, era también tribunal constitucional por cuanto era el ente encargado de dirimir sobre los posibles conflictos por las medidas a adoptar entre el Ejecutivo del Reich y la autoridad de los Länder ${ }^{92}$. El procedimiento por disolución de partidos o agrupaciones y reuniones, así como de prohibición de publicaciones, ante esta magistratura quedaba además perfilado a través del Decreto que establecía el procedimiento ante el Tribunal para la protección de la Repú-

${ }^{91}$ No obstante, parece que el plan de Ebert no solo estaba en crear un tribunal adicional de protección constitucional frente a este tipo de casos, sino también quitar esta función de protección extra de los juzgados ordinarios, en tanto muchos de sus miembros no parecían fieles a la República y despertaban ciertas desconfianzas. Véase así HuECK, I. J., Der Staatsgerichtshof zum Schutze der Republik (Tübingen: J.C.B. Mohr, 1996), 90.

${ }_{92}$ Hueck, I. J., Der Staatsgerichtshof zum Schutze der Republik..., 8. 
blica en cuestiones administrativas de 1 de agosto de $1922^{93}$. Igualmente, con el complementario de la norma alemana, la Ley de obligaciones del funcionariado para la protección de la República de Weimar, también de 21 de julio de $1922^{94}$, sucedía algo parecido. Esta norma, referida a los empleados públicos, obligaba, en efecto, a tener una relación de servicio compatible con la forma de Estado republicana y sancionaba la utilización del puesto público para hacer eco de proclamas contra la República o a favor de la Monarquía ${ }^{95}$, pero no llegaba a castigar la falta de celo y la negligencia, como hacía la norma española, y fijaba, además, a efectos sancionatorios administrativos por estas causas, la realización del correspondiente procedimiento disciplinario.

En cambio, como es sabido, en la norma española era el Ministro de Gobernación quien tenía mayores facultades cara a la aplicación de la ley y proceder motu proprio a la suspensión de reuniones, manifestaciones y asociaciones y proceder a la intervención de cualquier entidad privada que se entendiera podía ser contraria al régimen ${ }^{96}$; luego, el control judicial de las medidas y sanciones, como han probado Fernández Segado ${ }^{97}$ y Ballbé, era casi inexistente ${ }^{98}$.

En el caso alemán, toda esta normativa de excepción y, en concreto, la utilización del Ejército (Reichswehr) para resolver la situación de caos podían estar justificadas, sobre todo, como se ha visto, en el primer periodo de la República de Weimar. En España se puede decir que hay dos lecturas: una preventiva y una aperturista. Esta división sugiere en términos generales que, en efecto, cabría entender que en la II República, desde los primeros meses de su andadura, había riesgos de suficiente entidad (anarquistas, monárquicos, izquierda y derecha radical) como para el mantenimiento de la situación de excepción y la utilización constante del Ejército en orden a la protección del régimen ${ }^{99}$, mientras otros dejan entrever que las huelgas y conatos de tensión político-social no requerían una restricción tal de las garantías individuales

${ }_{93}$ Reichsgesetzblatt 1922 I, 675. Norma disponible en alemán en http://www.documentarchiv.de/wr.html.

${ }^{94}$ Gesetz über die Pflichten der Beamten zum Schutze der Republik, de 21 de julio de 1922, que reformaba la Reichsbeamtengesetz (Ley de Funcionarios del Reich) de 18 de mayo de 1907. Disponible en alemán en http://www.documentarchiv.de/wr/rbeamtepflicht_ges.html.

${ }_{95}$ Rudolf, B., «Verfassungsfeinde im öffentliche Dienst», en Thiel, M. (Coord.), Wehrhafte Demokratie (Tübingen: Mohr Siebeck, 2003), 214.

${ }^{96}$ Fernández Segado, F., «La defensa extraordinaria de la República», 116.

97 Fernández Segado, F., «La defensa extraordinaria de la República», 117.

98 Véase Ballbé, M., Orden público y militarismo..., 333.

99 Para una lista de autores en esta línea, véase la relación de Fernández Segado, F., «La defensa extraordinaria de la República», 111. 
ni, después, de los derechos constitucionales, como hacia la Ley de Defensa de la República, y que, quizás, la falta de apertura en este sentido y de ampliación de las libertades tras el fin de la Monarquía empujó la situación a una mayor inestabilidad ${ }^{100}$. Esta extensión de excepcionalidad, además, habría llevado a un exceso de uso de las fuerzas armadas como elemento de mantenimiento de orden público, que, a la postre habría llevado también a una progresiva mayor politización del gremio militar -en algunos casos integrando asociaciones de extrema derecha, la Unión Militar Española (UME), desafecta a la República, de carácter republicano-radical, como la Unión Militar Antifascista (UMA) y la Unión Militar Republicana Antifascista (UMRA) $)^{101}$-, con efectos igualmente desestabilizadores ${ }^{102}$.

La Ley de Protección de la República de 21 de julio de 1922 sería modificada por la Ley de 31 de marzo de 1926 y la Ley de 8 de julio de 1926, determinando su vigencia por un plazo de solamente cinco años, si bien, después, la Ley de 2 de junio de 1927 terminaría por darle dos años más de prórroga de vigencia ${ }^{103}$. La nueva Ley de Protección de la República (Zweite Gesetz zum Schutze der Republik) sería de 25 de marzo de $1930^{104}$. Esta norma era más rala y laxa, posiblemente porque la especial coyuntura de violencia en la que nació la primera Ley de Protección de la República, hacía ya ocho años, en 1922, había evolucionado, en particular, supuestamente ya no habría tanto riesgo a atentados terroristas de la ultraderecha frente a altos cargos. Es cierto es que continuaba habiendo choques y ataques entre nacionalsocialistas y comunistas, en especial en Berlín (particularmente intensos de 1927

${ }^{100}$ Véase, por ejemplo, PAyne, S. G., en El colapso de la República..., 565, cuando dice que «debe tenerse presente que la extensión de la violencia fue muy inferior durante los tres primeros años de la República, y que entonces no amenazó con desestabilizar el régimen. Sólo en 1934 se desarrolló violencia realmente seria». Respecto a los juicios críticos a la ley, por inconstitucional, véase de FERnÁNDEZ SEGADO, F., «La defensa extraordinaria de la República», 111 y 112; el mismo autor en Las Constituciones históricas españolas..., 463 y 464.

101 Véase Busquets Bragulat, J., «Conservadurismo, republicanismo y antirrepublicanismo en las fuerzas armadas», en Anales de Historia Contemporánea 7 (1989), 82.

102 Véase Salas LarrazÁBal, R., Historia del Ejército Popular de la República, Vol. I (Madrid: La Esfera, 2006), 106 y 107; el mismo autor en «Las reformas de Azaña», en Hernández SÁnchez-Barba, M., y Alonso Baquer, M. (Dir.), Historia social, 81-91; Cerezo Martínez, R., «La Armada española en el Siglo XX», 222-225; Ballbé, M., Orden público y militarismo..., 343-345.

103 HäntzsChel, K., y SchÖNNER, K., Gesetz zum Schutz der Republik (Reichsgesetz vom 25. März 1930 - RGBl. I. S. 91). Mit den Ausführungsbestimmungen des Reichs und der Länder. Unter besonderer Berücksichtigung der Rechtsprechung (Berlin: Verlag Stilke, 1930), 7.

${ }^{104}$ Reichsgesetzblatt 1930 I, 91-93. Norma disponible en alemán en <http://www. documentarchiv.de/wr.html>. 
a1929 ${ }^{105}$, pero probablemente estos altercados se verían ya más como una cuestión policial y de paz pública y que -en principio- no ponían tanto en absoluto riesgo la forma republicana del Estado. Los tipos de ilícitos, a saber la participación o colaboración para atentar contra la vida de una persona o los representantes del Gobierno del Reich o de un Land, se sancionaban ahora con pena de prisión que no podía ser inferior a tres meses de cárcel (artículo 1), si bien esto podía también depender cuando, por la normativa penal, hubiera lugar a una pena mayor. Igualmente se sancionaba el insulto a la forma constitucional republicana del Estado, la denigración maliciosa de los miembros del Ejecutivo del Reich o de los Ländern o el descrédito o improperios contra sus símbolos o su bandera ${ }^{106}$, como también de altos cargos fallecidos (artículo 5). La norma determinaba también la posibilidad de disolución policial de reuniones y manifestaciones (artículo 8), la suspensión de asociaciones (artículo 9), cuando prosiguieran los ilícitos ya vistos o alterasen el orden público, y, asimismo, en su caso, el cierre de publicaciones y periódicos (artículos 12 y siguientes). Fuera de los causas en que, por la naturaleza del delito, la sustanciación del procedimiento se realizara por la vía penal, la principal garantía en estos casos consistía en la posibilidad de recurso ante la autoridad administrativa competente del Land, en plazo de dos meses (sin efectos suspensivos), la cual podía resolver por sí misma en casos de menor importancia; si bien la competencia en apelación y en casos de mayor índole la tenía -ya no el Tribunal del Estado para la protección de la República-, sino una Sala de nueva creación, el Tribunal Administrativo del Reich (Reichsverwaltungsgericht), y hasta en tanto se implementara este ente judicial -de acuerdo al artículo 9.4- se encargaría de la resolución de causas por protección de la República una sala del Sala del Tribunal del Reich (Reichsgerichts). Ya antes, en 1927, se había producido el traspaso de competencias en materia de causas de protección de la República del Tribunal del Estado para la protección de la República a una Sala del Tribunal del Reich ${ }^{107}$; ahora, tras la aprobación de la nueva ley de 1930, se procedía a la creación de 124.

105 Véase Huey Liang, H., Die berliner Polizei in der Weimarer Republik..., 117-

${ }^{106}$ La bandera de la República alemana, negra, roja y amarilla oro, así como sus símbolos nacionales, se regularían por Decreto de 11 de abril de 1921 y por Decreto de 5 de mayo de 1925. HänTZSCHEL, K., y SchÖNNER, K., Gesetz zum Schutz der Republik... 31. El himno nacional alemán «Deutschland über alles», se adoptó por Orden del Reichspräsident de 11 de agosto de 1922. Véase WinKLER, H. A., Weimar 1918-1933..., 178. Para más detalles sobre el himno alemán, véase PETER HÄBERLE, El himno nacional como elemento de identidad cultural del Estado constitucional (Madrid: Dykinson, 2012), 55-57. Traducción del alemán del Alberto Oehling de los Reyes.

107 Schulz, G., Deutschland am Vorabend der Grossen Krisse..., 328. 
una magistratura ex novo, cuya regulación de procedimiento y recurso y competencias se delimitaría por el Decreto de 3 de abril de $1930^{108}$.

Fuera de esta normativa, cabría citar alguna otra disposición complementaria en relación al orden y seguridad pública, en particular el Decreto del Reichspräsident frente a disturbios políticos, de 28 de marzo de $1931^{109}$, también dictado bajo cobertura del artículo 48 de la Constitución de Weimar. Por esta norma se establecían, en particular, restricciones especiales respecto al derecho de manifestación, las libertades políticas, la libertad de expresión e imprenta. Respecto al derecho de manifestación, el artículo 1 y siguientes del Decreto determinaba la obligación de los organizadores de aviso previo a la autoridad competente -en un plazo mínimo de 24 horas- del lugar de la manifestación, itinerario, y razones de la misma, pudiéndose ésta prohibir cuando se presumiera que podía conllevar la desobediencia a las disposiciones legales vigentes, proferirse insultos o amenazas a cargos del Estado o que se pudiera faltar el respeto a instituciones públicas o comunidades religiosas. Obviamente quedaban fuera del ámbito de regulación de la norma las procesiones religiosas, los desfiles populares, las bodas, etc. Respecto a la libertad ideológica, de expresión, información y prensa, determinaba la posibilidad policial de confiscación de pancartas y octavillas y folletos propagandísticos cuando pudieran contener proclamas o afirmaciones contrarias al orden público (artículo 10). A tales efectos, preveía, antes de la colocación de pancartas y carteles, el trámite previo de información del contenido de las proclamas políticas a la autoridad policial, que, en su caso, podía proceder a su incautación y comiso. Ante esta situación, la posible impugnación de la orden de prohibición de manifestación o comiso, se realizaba de conformidad con el Derecho correspondiente del Land o bien, nuevamente, ante la Sala de del Tribunal del Reich (artículo 13) ${ }^{110}$.

108 Verordnung über das Verfahren in Verwaltungssachen auf Grund des Gesetzes zum Schutze des Republik, de 3 de abril de 1930. Reichsgesetzblatt 1930 I, 130. Norma disponible en alemán en $<$ http://www.documentarchiv.de/wr.html $>$.

109 Verordnung des Reichspräsidenten zur Bekämpfung politischer Ausschreitungen. Reichsgesetzblatt 1931 I, 79-81.

110 Esta norma se modificaría después en distintas disposiciones, en concreto por el Segundo Decreto del Reichspräsident frente a disturbios políticos, de 17 de julio de 1931 y de 10 de agosto de 1931. Posteriormente, quedaría complementado con el Decreto sobre Seguridad, Economía y Finanzas y frente a disturbios políticos, de 6 de octubre de 1931 (Verordnung des Reichspräsidenten zur Sicherung von Wirtschaft und Finanzen und zur Bekämpfung politischer Ausschreitungenl, y por el Decreto sobre Seguridad, Economía y Finanzas y protección de la Paz interior, de 8 de diciembre de 1931 (Verordnung des Reichspräsidenten zur Sicherung von Wirtschaft und Finanzen und zum Schutze des inneren Friedens). Normas disponibles en alemán en $<$ http://www.documentarchiv.de/wr. html>. 


\section{LA POST-NORMATIVA EN MATERIA DE DEFENSA INTERNA EXTRAORDINARIA DE LA REPÚBLICA}

Fuera de las previsiones puramente de carácter penal -contenidas bien en el Código Penal de 1871 o, posteriormente, en el de $1932^{111}$-, la II República desarrolló distintos tipos de instrumentos de protección del orden público y de defensa adicional del régimen, de restricción de libertades y suspensión de derechos y garantías en pro del orden público: ora de aplicación individual, ora general. En primer lugar, la Ley de Defensa de la República, vista anteriormente, que determinaba la suspensión de determinados derechos constitucionales de un sujeto por considerarlo un peligro para el régimen, por ejemplo, por desobediencia a la ley, violencia, apología de la Monarquía, por expresar su malestar respecto al Estado o las Instituciones o, como funcionario, por falta de celo en el cumplimiento del deber o (artículo 1). En segundo lugar, la Ley de Vagos y Maleantes, de 4 de agosto de 1933, que preveía una especial vigilancia policial, restricción de la libertad de circulación e incluso el internamiento en un centro de trabajo forzado (Título I, Capítulo III) por considerar a un sujeto peligroso para la seguridad pública (los vagos habituales, los rufianes, proxenetas, mendigos, etc. $)^{112}$. En tercer lugar, el artículo 42 de la Constitución de 9 de diciembre de 1931, que posibilitaba la suspensión de los derechos de libertad personal, libertad de circulación, inviolabilidad domiciliaria, libertad de expresión, reunión, asociación y sindicación, total o parcialmente, en todo el territorio nacional o en parte de él, por decreto del Gobierno. En cuarto lugar, hay que citar la facultad del Presidente de la República de disponer medidas urgentes en defensa de la integridad y seguridad de la Nación, del artículo 76.d, por ejemplo, por peligro frente a una invasión extranjera o por un peligro interno que supusiera un riesgo para la seguridad del régimen ${ }^{113}$.

Ahora bien, la restricción de las libertades y la suspensión de derechos en razón del orden público se observan en ningún otro punto con tanta claridad como en la Ley de Orden Público de $1933^{114}$, que se supone derogaba la Ley de Defensa de la República en todo aquello en lo que estuviera en contradicción $^{115}$. La norma clasificaba las facultades gubernativas de delimitación en dos niveles bajo centralización del Ministerio de Gobernación: facultades ordinarias y facultades extraordinarias que reunían el estado de prevención,

111 Gaceta de Madrid n. ${ }^{\circ}$ 310, de 5 de noviembre de 1932, pp. 818-856.

112 Gaceta de Madrid n. ${ }^{\circ}$ 217, de 5 de agosto de 1933, pp. 874-877.

113 Fernández Segado, F., «La defensa extraordinaria de la República», 123 y 124.

114 Gaceta de Madrid n. ${ }^{\circ}$ 211, de 30 de julio de 1933, pp. 682-699.

115 Véase PÉrez GIL, L. V., «Análisis de los principios constitucionales y las competencias en las relaciones exteriores de la Constitución española de diciembre 1931», en Revista Española de Derecho Constitucional 63 (2001), 135. 
el estado de alarma y el estado de guerra. Las facultades ordinarias, recaían sobre los Gobernadores Civiles, en su función de dirección de los agentes y cuerpos de seguridad. Estos tenían capacidad para disolver por la fuerza cualquier manifestación no autorizada, de carácter violento o en la que se produjeran agresiones a la fuerza pública (artículo 11). Más allá, el artículo 10 de la ley incluía la posibilidad de hacer fuego toda vez que los manifestantes hicieran fuerza contra los agentes y se profiriera, previamente, un segundo aviso de petición de disolución de la concentración. El estado de prevención, en cambio, debía ser declarado por el Ejecutivo, para una parte o todo el territorio nacional, y tomaba forma de decreto acordado por el Consejo de Ministros y firmado por el Presidente del Consejo. A través del decreto, la autoridad gubernativa quedaba habilitada para: solicitar notificación al ciudadano de cualquier cambio de domicilio o residencia que quisiera hacer, así como -en caso de viaje- de preaviso del itinerario que pretendía seguir; intervención de industrias y comercios, fiscalización policial previa de periódicos, pasquines, fanzines y octavillas de imprenta de tipo político ${ }^{116}$ y restricción de los derechos de reunión, circulación, asociación, sindicación y huelga (artículo 27). En el caso de que la cosa fuera a más y no bastase con la declaración del estado de prevención, el Gobierno, en casos de notoria e inminente gravedad, podía declarar el estado de alarma y suspender -también por decreto- las garantías citadas del artículo 42 de la Constitución, total o parcialmente, en todo el territorio nacional o en parte de él; luego, la autoridad quedaba habilitada para prohibir la formación de grupos y concentraciones en la vía pública y establecer censura previa sobre todo tipo de impresos y publicaciones. El estado de guerra, en fin, supondría el máximo estadio de restricción y presuponía no ya la participación del Ejército -que podía colaborar también en los supuestos anteriores con la autoridad civil (artículo 48)-, sino que la autoridad militar fuera la que adoptara específicamente las medidas necesarias para el restablecimiento del orden público. En efecto, en caso de rebelión o sedición violenta, el Gobierno, podía dictar el estado de guerra, bien en una parte del territorio o, incluso, en toda España; haciéndose cargo del mando la

${ }^{116}$ Como pone de manifiesto Cruz, había una treta utilizada por el Partido Comunista para tratar de esquivar las duras exigencias de la Ley de Orden Público de 1933. Se trataba de culpar de la autoría o dirección de las publicaciones a uno de los diputados comunistas en el Congreso, a fin de utilizar su inmunidad parlamentaria como freno a la aplicación de la aplicación de la sanción. El diputado era advertido, por algún funcionario judicial «amigo», de la incoación de la incoación de un proceso contra el artículo o el periódico, lo que permitía al diputado personarse previamente ante el órgano judicial para responsabilizarse de la publicación; luego, entere que el juez pedía el suplicatorio al Congreso a efectos de su procesamiento y entre la denegación sistemática del mismo por la cámara, se hacía forzar su archivo e inanidad del hecho. Véase, así, CRUZ, R., «La prensa madrileña durante la II República», 359 y 361. 
autoridad militar designada que sería la encargada de publicar los oportunos bandos y edictos y prevenciones necesarias para reducir la revuelta (artículo 53). La norma también incluía la posibilidad de formación de consejos de guerra para el enjuiciamiento de los detenidos, sometidos temporalmente a la jurisdicción militar, de conformidad con lo dispuesto en el artículo 95, párrafo tercero, de la Constitución; luego, una vez levantado el estado de alarma por el Ejecutivo, las causas tramitadas por la jurisdicción militar pasaban a los tribunales ordinarios competentes ${ }^{117}$. El ejemplo tipo de estado de guerra fue el declarado con motivo de la Revolución de 1934, que afectó a toda España ${ }^{118}$. Se calcula que murieron de 1.500 a 2.000 personas, y casi 3.000 resultaron heridas. De los muertos, unos 320 eran guardias civiles, soldados, guardias de asalto y carabineros; luego hubo hasta alrededor de 30.000 detenidos en todo el país ${ }^{119}$. Incluso, las recompensas que se dieron a los militares que participaron en la reducción de la Revolución de octubre de 1934 se determinó que se considerasen conseguidas por «hechos de guerra» ${ }^{120}$.

El Decreto de 16 de septiembre de 1935 desarrollaba algunos aspectos de la Ley de Orden Público de 1933. Incidía en la competencia del Ministro de Gobernación en materia de dirección del orden público general, quien podía delegar en orden a la coordinación de operaciones de seguridad en el Delegado General de Seguridad de Madrid, el Delegado del Poder Central en las Regiones, el Gobernador Civil y, en su caso, en el Alcalde. Estos cargos, como autoridad competente, podían dictar bandos y circulares para la publicitación de medidas de orden público. Obviamente, en casos de alteración de la seguridad interior, el mando no se reducía a la Guardia Civil, Carabineros, Guardias de Asalto y Guardias Municipales, sino también a otro tipo de institutos policiales y de vigilancia. Como los Migueletes de Guipúzcoa, los Miñones de Vizcaya y Álava, los Mozos de Escuadra de Barcelona e incluso los Vigilantes de Caminos, Guardas Forestales y Peones Camineros. En caso de estado de guerra, los miembros de estos institutos o servicios pasaban a depender directamente de la autoridad militar, salvo en las cuestiones que ésta delegase o dejase expeditas a las autoridades civiles ${ }^{121}$.

117 Véase así, por ejemplo, el Decreto de 23 de enero de 1935. Gaceta de Madrid n. ${ }^{\circ}$ 24, de 24 de enero, p. 707.

118 Véase el Decreto declarando el estado de guerra en todo el territorio de la República Española. Gaceta de Madrid n. ${ }^{\text { }}$ 280, de 7 de julio de 1934, p. 194.

119 Thomas, H., Salas LarrazÁBal, R., y Viñas, V., La Guerra Civil española, Vol. I..., 261 y 262.

${ }^{120}$ De hecho, las recompensas que se dieron a los militares que participaron en la reducción de la Revolución de octubre de 1934 se determinó que se considerasen conseguidas por «hechos de guerra», por Orden de 27 de noviembre de 1934. Gaceta de Madrid n. $^{\circ}$ 333, de 29 de noviembre, p. 1.696.

${ }^{121}$ Gaceta de Madrid n. ${ }^{\circ}$ 260, de 17 de septiembre de 1935, pp. 2146-2150. 
TITLE: The Law of defense of the Republic of October 21, 1931: Introduction to its political-legal context, to its related and brief comparative regulations with its German counterpart Gesetz zum Schutze der Republik

RESUMEN: Para analizar el grado de eficacia y validez de los derechos y libertades constitucionales de la Constitución de 9 de diciembre de 1931 y de la II República española debe tenerse en cuenta la vigencia de la Ley de Defensa de la República de 21 de octubre de 1931, pero, además, hay que observar también otras leyes de orden público que caracterizaron su contexto politicojurídico. Por una parte, hay que estudiar la extensión de vigencia en la II República de normas de la época de la Monarquía y la Dictadura de Primo de Rivera; por otra parte, hay que analizar el grado de delimitación de derechos y libertades que derivaba de la propia normativa adicional en materia de seguridad y orden público aprobada ya por el poder constituido republicano, en particular, la Ley de Vagos y Maleantes, de 4 de agosto de 1933, o la Ley de Orden Público de 1933. Aparte, se realiza una breve comparativa con la Ley de Protección de la República alemana de Weimar (Gesetz zum Schutze der Republik), que creemos también puede ser útil a efectos de contextualizar y valorar político-jurídicamente la oportunidad o no y excesos de la Ley de Defensa de la República española.

PALABRAS CLAVE: II República española, Constitución de 9 de diciembre de 1931, República de Weimar, orden público, seguridad pública, vigencia y restricción de derechos y libertades constitucionales.

ABSTRACT: In order to anayze the validity and effectiveness of the constitutional rights and freedoms in the Constitution of 9 th December 1931 and the Second Spanish Republic, should be considered the Act of the Republic's Defense of 21 October 1931, but also should be considered other legislation about public order, that characterized its political-legal context. On the one hand, must be analyzed the adoption and validity in the Second Republic of the monarchy's rules and the Primo de Rivera's dictatorship. On the other hand, must be analyzed the level of delimitation of rights and freedoms delimitation, which resulted from the own legislation on security and order-public approved by the legislative in the Second Republic; for example, the Vagrancy Act of 4 august 1933 and the Public Order Act 1933. In addition, it has been included a short comparative with the Act on Protection of the Weimar Republic (Gesetz zum Schutze der Republik), that aldo we believe it may be particularly useful to contextualize and analyze in legal and political form the oportunity of the Act of the Republic's Defense in the Second Spanish Republic and its possible excessive provisions.

KEY WORDS: Second Spanish Republic, Constitution of 9 December 1931, Weimar Republic, public order, public security, validity and restrictions of the constitutional rights and freedoms.

RECIBIDO: 10.10 .2016

ACEPTADO: 19.12.2016 